\title{
Potential of Local Microalgae as A Natural Antioxidant to Produce Asuh Broiler Meat
}

\author{
Salvia ${ }^{1}$, Mirzah $^{2}$, Yetti Marlida ${ }^{2}$, Endang Purwati ${ }^{2}$ \\ ${ }^{1}$ Program Study of Animal Science, Polytechnic of Agricultural, \\ Andalas University,Payakumbuh \\ E-mail: xxx@yyy.zzz. \\ ${ }^{2}$ Faculty of Animal Science, Andalas University Padang, West Sumatera, Indonesia \\ E-mail: salviasani@ymail.com
}

\begin{abstract}
Feed quality for food safety. To produce ASUH (safe, healthy, whole and halal) food from broiler, it should be fed with quality ration that free from chemical residues derived from synthetic antioxidants such as BHT, BHA and antibiotic for the meat contained residue that will cause negative effect. Microalgae has the potential to be used as natural supplement because it contains nutrients, antioxidant, cholesterolemic effect and plant growth regulator. Ojectives of this study is to exploit natural antioxidant substance in local microalgae extract as natural supplement for broiler. This research used local microalgae collected from water of the pond located around chicken farm in Nagari Mungka, 50 Kota District. DPPH free radical absorbance method used to test antioxidant activity, while ascorbic acid (Vitamin C) used as comparison, and was tested to broiler to oversee its performance. Best concentration tested to broilers and its performances was observed. The result of study ; Local microalgae extract has ability to inhibit DPPH free radical by concentration at $80 \mu \mathrm{g} / \mathrm{ml}$ which is equal to $6 \mu \mathrm{g} / \mathrm{ml}$ of Vitamin C. The performance after giving microalgae as antioxidant is better than Vitamin $\mathrm{C}$ because it contains nutrition and others secondary metabolic such as antimicrobial, cholesterolimic effect and plant growth regulator. Local microalgae is potential as source of natural antioxidants for producing ASUH broiler meat
\end{abstract}

Keywords - Microalgae, Antioxidant Activity, ASUH Chicken Meat.

\section{INTRODUCTION}

This Feed quality for food safety. To produce ASUH (safe, healthy, whole and halal) food from broiler , it should be fed with quality ration that free from chemical residues derived from synthetic antioxidants such as BHT, BHA and antibiotic for the meat contained residue thal will cause negative effect. Broiler meat is one food that is declared less safe for consumers because it is assumed to contain high cholesterol and chemical residues derived from feed additive which added to commercial rations in order to trigger the growth of chickens and as a preservative. The residue of feed additive left inside the chicken and this will trigger the development of a disease such as hypertension, coronary heart disease and cancer for those who consume it.

Considering the dangers of chemical residues, there should be an exploration of the natural ingredients that are safer to feed suplement. Many reports say that microalgae contains active compound such as antibiotic, antiviral, cytotoxic and antimitotic activities. Microalgae is known to contain antioxidant molecules, such as ascorbate and glutathion (GSH), including carotenoid ( Yuan at al, 2005). Microalgae has the potential to be used as natural antioxidant. It is also contains nutrients, cholesterolemic effect and plant growth regulator (Kamase, 2007). Thus, the objectives of this study is to exploit natural antioxidant substance in local microalgae extract as natural supplement for broiler.

\section{MATERIAL AND METHOD}

This research used local microalgae collected from water pond located around chicken farm in Nagari Mungka, 50 Kota District. DPPH free radical absorbance method used to test antioxidant activity by Vachos et al (1996). while ascorbic acid (Vitamin C) used as comparison, and was tested to broiler to oversee its performance. The examination of antioxidant activity on local microalgae with concentration; $10 \mu \mathrm{g} / \mathrm{ml}, 20 \mu \mathrm{g} / \mathrm{ml}, 40 \mu \mathrm{g} / \mathrm{ml}, 60 \mu \mathrm{g} / \mathrm{ml}$, $80 \mu \mathrm{g} / \mathrm{ml}$ dan $100 \mu \mathrm{g} / \mathrm{ml}$. Consentration of ascorbic acid are: $1 \mu \mathrm{g} / \mathrm{ml}, 2 \mu \mathrm{g} / \mathrm{ml}, 3 \mu \mathrm{g} / \mathrm{ml}, 4 \mu \mathrm{g} / \mathrm{ml}, 5 \mu \mathrm{g} / \mathrm{ml}$ dan $6 \mu \mathrm{g} / \mathrm{ml}$. A $10 \mathrm{mg}$ extract dissolved with $10 \mathrm{ml}$ methanol in a $10 \mathrm{ml}$ 


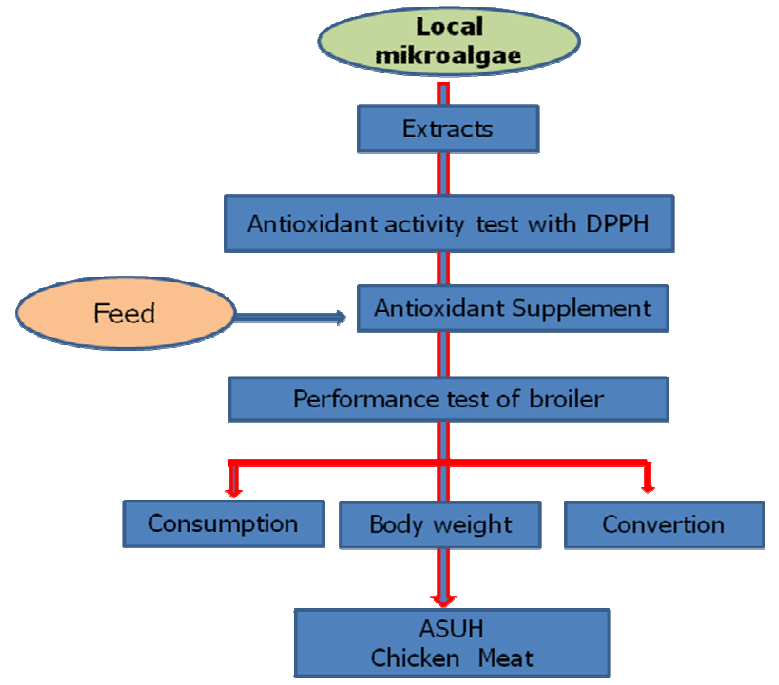

Fig. 1. Research Flow Chart

erlemeyerad to produce $1 \mu \mathrm{g} / \mathrm{ml}$ concentration. Methanol was added to dilute it in order to ge sample with vary concentration $(10,20,40,60,80$ dan $100 \mu \mathrm{g} / \mathrm{ml})$. The determination of antioxidant activity of each concentrartion done in micro pipette and pour it into the vial. Then, a $3.8 \mathrm{ml}$ DPPH $50 \mu \mathrm{M}$ solution added. The mixture was homogenized and stored in dark room for 30 minutes. The absorbance measured by means spectrofotomenter UV-VIS at $515 \mathrm{~nm}$ wave length. Ascorbic acid (concentration 1,2,3,4,5,6 $\mu \mathrm{g} / \mathrm{ml}$ ) used as comparison.

Best concentration tested to broilers and its performances was observed. There were 75 DOC broilers used as sample of the research. Best concentration of microalage gained from DPPH free radical inhibitation test, which is biologically tested and its performance was observed. As comparison Vitamin C with equivalent concentration with above test result used. The Complete Randome Design with 3 treatments and 5 replication used in this research.

Sample antioxidant activity was determined by the rate of DPPH free radical absorbance inhibition by calculating the precentage of DPPH absorbance inhibition using the following formula:

Abs control - Abs Sample

$\%$ Inhibition $=$ x $100 \%$

(1)

Explanation:

\section{Abs Control}

Abs control : $50 \mu \mathrm{M}$ DPPH free radical absorbance at $515 \mathrm{~nm}$ wave length.

Abs sample : sample absorbance to $50 \mu \mathrm{M}$ DPPH free radical at $515 \mathrm{~nm}$ wave length.

Result data of biological test processed with mini Tab software.

\section{RESULTS AND DISCUSSION}

\section{A. Antioxsidant activity}

Table 1 shows antioxidant activity of micro algae extract and Vitamin C using DPPH method while Table 2 exhibits performance of broiler given microalgae supplement for 4 weeks.

TABLE I

ANTIOXIDANT ACTIVITY OF LOCAL MICROALGAE (CONSORTIUM) EXTRACTS

\begin{tabular}{|c|c|c|c|}
\hline Comparison & $\begin{array}{l}\text { Concentration } \\
\mu \mathrm{g} / \mathrm{ml}\end{array}$ & Absorbance & $\begin{array}{l}\% \\
\text { Inhibition }\end{array}$ \\
\hline \multirow{6}{*}{ Microalgae } & 10 & 0.238 & 57,64 \\
\hline & 20 & 0,191 & 65,83 \\
\hline & 40 & 0,143 & 74,55 \\
\hline & 60 & 0,118 & 78,94 \\
\hline & 80 & 0,045 & 89,56 \\
\hline & 100 & 0,041 & 92,88 \\
\hline \multirow{6}{*}{ Vitamin C } & 1 & 0,322 & 23,34 \\
\hline & 2 & 0,314 & 33,88 \\
\hline & 3 & 0,297 & 49,55 \\
\hline & 4 & 0,189 & 54,01 \\
\hline & 5 & 0,109 & 79,86 \\
\hline & 6 & 0,062 & 88,25 \\
\hline
\end{tabular}

Local microalgae extract has ability to inhibit DPPH free radical by concentration at $80 \mu \mathrm{g} / \mathrm{ml}$, which is equal to 6 $\mu \mathrm{g} / \mathrm{ml}$ of Vitamin C. The performance after giving microalgae as antioxidant is better than Vitamin $\mathrm{C}$ because it contains nutrition and others secondary metabolic such as antimicrobial, cholesterolimic effect and plant growth regulator. 
TABLE I

PRODUCTION OF ASUH BROILER NEAT RAISED FOR 4 WEEKS

\begin{tabular}{|l|l|l|l|}
\hline Component & Feed Consumption & Body Weight & Feed Convertion \\
\hline & & & \\
\hline Non supplement & 1578,00 a & 1075,00 a & 1467,00 a \\
\hline Local microalgae & & & 1212,00 b \\
\hline Vitamin C & 1587,00 a & 1313,00 b & \\
\hline & & & 1297,00 c \\
\hline
\end{tabular}

Mean values with different superscripts in the same column are significantly different $(\mathrm{p} \leq 0.05)$

\section{CONCLUSIONS}

Local microalgae is potential as source of natural antioxidants for producing ASUH broiler meat.

\section{REFERENCES}

[1] Angka. T.Soeharto.2000, Pengaruh konsentrasi nutrien terhadap pertumbuhan dan produktivitas Chlorella sp.pada kultur semikontinyu. LIMNOTEK 2(1) (1994) 33--43.
[2] Anonim. 2004. Porphyridium cruentum composition. www.necton.pt/Algae, 11 mei 2004

[3] Basmi, J., 1994. Blooming Fitoplankton, Fakultas Perikanan, Institut Pertanian Bogor, Bogor.

[4] Becker FW. 1994. Microalgae biotechnology and microbiology. New York: Cambridge University Press.

[5] Borowitzka MA, Borowitzka LJ. 1988. Mikroalgal biotechnology. Cambridge: Cambridge University Press.

[6] Bornwitzka. al. 1998. An antibacterial and antiviral produced by Enterococcus mundtii ST4V isolated from soya beans. Int. J. of Antimicrobial Agents 25: 508-513

[7] British Pharmacopeia commision. 1993. British pharmacopeia. Vol. II. London: Her Majesty's stationery office;. hal. 167-8. 